\title{
PASAR TRADISIONAL: STUDI KASUSPASAR WISATA 46 DAN PASAR WISATA CIBIRU, KELURAHAN CIPADUNG, KECAMATAN CIBIRU
}

\author{
THE TRADITIONAL MARKET: \\ CASE STUDY OF PASAR WISATA 46 AND PASAR WISATA CIBIRU \\ IN CIPADUNG DISTRICT OF CIBIRU SUBDISTRICT
}

\author{
Ali Gufron \\ Balai Pelestarian Nilai Budaya Bandung \\ Jl. Cinambo 136 Ujungberung, Bandung \\ e-mail: pepeng_79@yahoo.co.id
}

\begin{abstract}
Abstrak
Di Kelurahan Cipadung ada dua pasar tradisional, yaitu Pasar Wisata 46 dan Pasar Wisata Cibiru. Pasar Wisata Cibiru didirikan untuk menampung para pedagang Pasar Wisata 46. Namun, yang menarik adalah para pedagang Pasar Wisata 46 sebagian besar enggan beralih ke Pasar Wisata Cibiru, sehingga perlu dilakukan penelitian dengan pokok masalah mengapa mereka sebagian besar tetap berjualan di Pasar Wisata 46. Padahal, secara fisik bangunan Pasar Wisata Cibiru lebih permanen, lebih bersih, dan fasilitasnya lebih lengkap daripada Pasar Wisata 46. Metode yang digunakan dalam penelitian ini adalah kualitatif. Adapun teknik yang digunakan untuk menjaring data dan informasi adalah wawancara dan observasi. Hasilnya ada beberapa faktor yang membuat sebagian besar para pedagang Pasar Wisata 46 enggan pindah ke Pasar Wisata Cibiru, yaitu: lokasi pasar dinilai kurang strategis, kios relatif kecil, biaya sewa relatif mahal, retribusi juga relatif mahal, status pedagang termasuk dalam kategori sektor informal, dan sebagian pedagang menganggap bahwa berjualan di Pasar Wisata 46 hanya merupakan pekerjaan sambilan dan atau sebagai uji coba untuk merintis usaha baru.
\end{abstract}

Kata kunci: pasar tradisional, pedagang kaki lima, sektor informal.

\begin{abstract}
In Cipadung regency established two traditional markets. There are Pasar Wisata 46 and Pasar Wisata Cibiru. The reason of building up Pasar Wisata Cibiru is to intercept seller from Pasar Wisata 46. The interesting one is most of the seller in Pasar Wisata 46 unwilling to move to Pasar Wisata Cibiru, so it needs to do a research to find out the reason behind it. Whereas, the building material and other facilities better than the Pasar Wisata 46. The method used in this research is qualitative method. The technique in collecting the data and other information are interview and observation. The result, why they won't move to Pasar Wisata Cibiru is because of the location seem not in the strategic area, the size of the kiosk is too small, the rent and retributions payment is more expensive, the status of the seller is in the informal category and they feel what that they sell in Pasar Wisata 46 only part-time activity or as a trial.
\end{abstract}

Keywords: the traditional market, informal seller, informal sector. 


\section{A. PEndahuluan}

Pasar dalam suatu masyarakat, baik di perkotaan maupun pedesaan, mempunyai peranan yang penting sebagai tempat mencari kebutuhan sehari-hari yang tidak dihasilkan sendiri. Sedikitnya ada tiga versi mengenai definisi pasar. Versi pertama berasal dari Ginanjar (1980) yang menyatakan bahwa pasar adalah tempat untuk menjual dan memasarkan barang atau sebagai bentuk penampungan aktivitas perdagangan. Versi kedua mendefinisikan pasar sebagai tempat pembeli bertemu dengan penjual, dimana terdapat barangbarang atau jasa-jasa yang ditawarkan untuk dijual dan kemudian terjadi pemindahan hak milik (Stanton, 1996). Sedangkan, berdasarkan Keputusan Menteri Perindustrian dan Perdagangan Nomor 23/MPP/KEP/1/1998, pasar didefinisikan sebagai tempat bertemunya pihak penjual dan pembeli untuk melaksanakan transaksi di mana proses jual beli terbentuk.

Apabila dilihat menurut kelas pelayanannya, pasar dapat digolongkan menjadi dua, yaitu pasar tradisional dan pasar modern. Pasar tradisional adalah pasar yang dibangun oleh pemerintah, swasta, koperasi atau swadaya masyarakat dengan tempat usaha berupa toko, kios, los dan tenda yang dimiliki/dikelola oleh pedagang kecil dan menengah atau koperasi dengan usaha skala kecil dan modal kecil dan dengan proses jual beli melalui tawar menawar. Pasar ini umumnya tumbuh secara spontan berdasarkan kebutuhan dari masyarakat dan menggunakan lokasi yang tidak semestinya diperuntukkan sebagai pasar. Sebaliknya, pasar modern merupakan sebuah pasar yang menyuguhkan barangbarang kebutuhan dengan harga pasti (tidak ada proses tawar menawar) (Putra, 2010: 1).

Dewasa ini, terutama di perkotaan, khususnya kota-kota besar, seperti: Jakarta, Surabaya, Yogyakarta, Semarang, dan Bandung bermunculan pasar-pasar modern (minimarket, supermarket, mall, plaza, dan hypermarket). Keberadaan pasar modern yang menjamur itu dikhawatirkan akan menggeser peranan pasar tradisional (Sumintarsih, dkk., 2011:3). Menurut penulis, menjamurnya tempat-tempat perbelanjaan modern tidak terlalu menjadi sesuatu yang merisaukan. Sebab, tingkat/kelas ekonomi masyarakat kita tidak sama (ada kelas bawah, kelas menengah, dan kelas atas) dan masingmasing mempunyai pangsa pasar tersendiri. Di Bandung misalnya, Pasar Caringin, Pasar Ujungberung, dan Pasar Gedebage tetap ada pengunjungnya. Demikian juga pasar yang berada di Kelurahan Cipadung, Kecamatan Cibiru, Kota Bandung, yaitu Pasar Wisata 46 yang mulai ada sekitar tahun 2004 dan Pasar Wisata Cibiru yang dibangun tahun 2012 untuk merelokasi para pedagang Pasar Wisata 46.

Pasar Wisata 46 dan Pasar Wisata Cibiru merupakan salah satu jenis pasar tradisional. Namun demikian, apabila ditinjau menurut waktu keberlangsungannya, Pasar Wisata Cibiru merupakan pasar harian atau pasar yang buka setiap hari. Sedangkan, Pasar Wisata 46 dapat dikategorikan sebagai pasar mingguan atau lebih dikenal dengan nama "pasar kaget" yang hanya ada setiap satu minggu sekali. Pasar kaget adalah salah satu jenis pasar tradisional dengan kegiatan pasar yang sifatnya sementara dengan wadah berjualan yang tersedia tidak permanen atau semi permanen dan aktivitasnya hanya untuk waktu-waktu tertentu selama beberapa jam saja, baik pada pagi hari ataupun sore hari (Putra 2010: 1).

Sesuai dengan sifatnya yang hanya sementara, mayoritas pedagang di pasar wisata 46 adalah pedagang kaki lima (PKL) dengan wadah berjualan yang tidak permanen atau semi permanen. Widjajanti (2009), mendefinisikan pedagang kaki lima (PKL) sebagai sekelompok orang yang menawarkan barang dan jasa untuk dijual di atas trotoar atau di tepi jalan, di sekitar pusat perbelanjaan/pertokoan, 
pasar, pusat rekreasi/hiburan, pusat perkantoran dan pusat pendidikan, baik secara menetap atau setengah menetap, berstatus tidak resmi atau setengah resmi dan dilakukan baik pagi, siang, sore, maupun malam hari.

Satu hal yang menarik, walau telah diberikan tempat yang relatif lebih nyaman dan bersih, tidak serta merta mengubah pendirian para pedagang Pasar Wisata 46 untuk beralih ke Pasar Wisata Cibiru. Sebagian besar tetap memilih berjualan sebagai pedagang kaki lima di sepanjang Jalan Cigagak hingga Jalan Kelurahan Cipadung. Oleh karena itu, penelitian tentang kedua pasar tradisional tersebut perlu dilakukan dengan masalah: Bagaimana bentuk Pasar Wisata 46 dan Pasar Wisata Cibiru serta mengapa pedagang lebih memilih berjualan di Pasar Wisata 46 daripada Pasar Wisata Cibiru. Adapun tujuannya adalah untuk menggambarkan bentuk Pasar Wisata 46 dan Pasar Wisata Cibiru serta mengetahui sebab-sebab mengapa para pedagang lebih memilih berjualan di Pasar Wisata 46 daripada Pasar Wisata Cibiru. Adapun materi yang akan dibahas meliputi: bentuk dan kondisi Pasar Wisata 46 serta Pasar Wisata Cibiru, para pedagang di kedua pasar, jenis-jenis barang dan jasa yang dijual, pengelola pasar, dan aturan-aturan yang diberlakukan terhadap pengelola maupun pedagang.

Penelitian tentang pasar sebagai tempat bertemunya antara penjual dan pembeli untuk mengadakan tukar-menukar (transaksi) barang dan jasa sebenarnya sudah banyak dilakukan orang, antara lain Sumintarsih, dkk (2011) dan Sadilah, dkk (2011). Penelitian Sumintarsih dkk., yang berjudul "Eksistensi Pasar Tradisional: Relasi dan Jaringan Pasar Tradisional di Kota Surabaya, Jawa Timur" menyimpulkan bahwa keberadaan pasar tradisional sangat diperlukan oleh mereka yang ada di segmen menengah ke bawah. Selain itu, pasar tradisional mempunyai peran yang sangat penting terhadap kehidupan orang banyak (pemasok hasil bumi, pedagang, pengelola pasar, tukang parkir, buruh angkut, dan sebagainya yang kehidupannya bertumpu pada keberadaan pasar. Oleh karena itu, keberadaan pasar tradisional harus dilestarikan (dilindungi, dikembangkan, dan dimanfaatkan). Simpulan yang sama juga diketengahkan oleh Sadilah dkk., melalui penelitiannya yang berjudul "Eksistensi Pasar Tradisional: Relasi dan Jaringan Pasar Tradisional di Kota Semarang, Jawa Tengah".

Penelitian Pasar Wisata 46 dan Pasar Wisata Cibiru juga tentang pasar tradisional. Meskipun demikian, penekanannya berbeda. Dalam hal ini, jika Sumintarsih, dkk. dan Sadilah, dkk. lebih menekankan pada aspek relasi dan jaringannya, maka penelitian Pasar Wisata 46 dan Pasar Wisata Cibiru lebih menekankan pada persoalan mengapa pedagang Pasar Wisata 46 enggan beralih ke Pasar Wisata Cibiru yang dibangun secara permanen.

\section{B. METODE PENELITIAN}

Penelitian ini bersifat deskriptifanalisis dengan pendekatan kualitatif, yaitu penggambaran sesuatu peristiwa yang sedang terjadi, kemudian mengaitkan antara variabel yang satu dengan lainnya tanpa mempergunakan pengujian statistik. Teknik pengumpulan data yang digunakan adalah wawancara yang bebas tetapi mendalam dan observasi (pengamatan). Wawancara ditujukan kepada tokoh formal (lurah), pengelola pasar, pedagang, dan pembeli. Melalui para informan tersebut diperoleh data dan informasi berupa: (1) Data sekunder berkenaan dengan Kelurahan Cipadung; (2) Asal usul Pasar Wisata 46 dan Pasar Wisata Cibiru; (3) Waktu, tempat, jenis dagangan, dan aturan yang berlaku di pasar; dan (4) Penilaian terhadap Pasar Wisata 46 jika dibandingkan dengan Pasar Wisata Cibiru. Lalu, dengan observasi di samping akan diperoleh data-data yang berkenaan dengan kondisi fisik pasar, juga aktivitas 
masyarakat yang berkaitan dengan Pasar Wisata 46 dan Pasar Wisata Cibiru.

Selain metode beserta teknikteknik di atas, studi literatur (kepustakaan dan atau dokumentasi) juga dilakukan dalam kegiatan ini. Studi literatur dilakukan dalam rangka memperoleh pengertian-pengertian atau konsep-konsep yang berkenaan dengan pasar, pasar tradisional, pasar modern, pasar kaget, dan pedagang kaki lima.

\section{HASIL DAN BAHASAN}

\section{Sekilas tentang Kelurahan Cipadung}

Kelurahan Cipadung secara administratif termasuk dalam wilayah Kecamatan Cibiru, Kota Bandung dengan batas-batas: sebelah utara dengan Kelurahan Palasari, sebelah selatan dengan Kelurahan Cipadung Wetan, sebelah barat dengan Kelurahan Palasari, dan sebelah timur berbatasan dengan Kelurahan Pasirbiru. Kelurahan yang memiliki luas sekitar 105 hektar ini dihuni oleh 12.167 jiwa atau 388 kepala keluarga (KK) yang terdiri atas 6.518 laki-laki $(53,57 \%)$ dan 5.649 perempuan $(46,43 \%)$. Jika dilihat berdasarkan golongan usia, penduduk yang berusia 0-12 tahun ada 4.312 jiwa $(35,44 \%)$, kemudian yang berusia $13-50$ tahun ada $6.302(51,80 \%)$, dan yang berusia 51 tahun ke atas 953 jiwa (7,83\%).

Jenis mata pencaharian yang digeluti oleh warga masyarakat Kelurahan Cipadung sangat beragam, yaitu: pegawai negeri di berbagai instansi pemerintah, (kelurahan, kecamatan, pemerintah daerah, perguruan tinggi, dan lain sebagainya), dan yang bekerja di non-pemerintah (karyawan swasta, wiraswasta, pedagang keliling, perajin, seniman, peternak, tukang, montir, petani, dan lain sebagainya).

Pola pemukiman penduduk umumnya berjajar dengan arah menghadap ke jalan, baik itu jalan provinsi maupun kecamatan. Rumah-rumah yang bukan di pinggir jalan pun arahnya mengikuti yang berada di pinggir jalan. Selain rumahrumah yang dibangun warga secara perorangan yang cenderung kurang beraturan, di wilayah Kelurahan Cipadung juga terdapat perumahan yang dibangun oleh pengembang perumahan swasta. Perumahan yang bentuk dan ukurannya sama itu terdapat di hampir seluruh wilayah kelurahan, termasuk di wilayah Rukun Warga 15, yaitu Perumahan Griya Cipadung Asri. Di depan Perumahan Griya Cipadung Asri ini terdapat Pasar Wisata 46 dan Pasar Wisata Cibiru yang menyediakan segala macam barang kebutuhan hidup.

\section{Pasar Wisata 46}

a. Letak Pasar Wisata 46

Pasar Wisata 46 terletak di sepanjang Jalan Cigagak hingga Jalan Kelurahan Cipadung. Pada awal berdirinya, sekitar pertengahan tahun 2004, pasar yang beroperasi setiap hari Minggu ini hanya terdiri atas beberapa orang pedagang makanan dan minuman. Tujuannya adalah untuk memenuhi kebutuhan bagi warga perumahan Griya Cipadung Asri dan siswa-siswi penghuni asrama Krida Nusantara yang sedang berolahraga di sepanjang Jalan Cigagak, serta para orang tua yang datang menjenguk putra-putri mereka yang bersekolah di Yayasan Pendidikan Krida Nusantara.

Seiring berjalannya waktu, jumlah orang yang berolahraga serta para orang tua yang datang menjenguk anaknya semakin bertambah, sehingga membuat banyak pedagang di sekitar Kecamatan Cibiru dan Cileunyi tertarik untuk berjualan di sana. Jenis barang yang didagangkan pun semakin beragam. Dalam hal ini tidak hanya makanan dan minuman, tetapi juga kebutuhan lainnya, seperti sandang, peralatan rumah tangga, dan asesories. Bertambahnya para pedagang membuat ruas jalan di sekitar Yayasan Pendidikan Krida Nusantara semakin menyempit (berkurang). Kehadiran para pedagang tersebut membuat pihak pengelola Yayasan Krida Nusantara merasa terganggu. Oleh karena itu, pihak pengelola yayasan melarang mereka 
berjualan di sekitar jalan yang menuju kawasan pendidikan tersebut.

Ketiadaan lahan usaha akibat pelarangan berjualan dimanfaatkan oleh pihak pengurus Rukun Warga 15, Kelurahan Cipadung, untuk mewadahi para pedagang. Adapun lokasinya berada di Jalan Cigagak, tepatnya di depan SMP Negeri 46 Bandung dan Griya Cipadung Asri. Lokasi yang jaraknya hanya sekitar 400 meter dari Yayasan Pendidikan Krida Nusantara ini akhirnya menjadi sebuah "pasar kaget" yang diberi nama "Pasar Wisata 46". Nama tersebut disesuaikan dengan lokasinya, yaitu di depan pintu gerbang SMP Negeri 46 Bandung.

Pada awalnya keberadaan Pasar Wisata 46 yang beroperasi setiap hari Minggu (dari pukul 06.00-10.30 WIB) ini ada sebagian warga Griya Cipadung Asri yang merasa terganggu karena di depan pagar rumah mereka dijadikan sebagai tempat berjualan. Alasannya, mereka tidak dapat leluasa keluar-masuk rumah. Selain itu, ketenteraman mereka terganggu karena adanya keberisikan yang ditimbulkan oleh aktivitas para pedagang dan pembeli, khususnya ketika sedang bertransaksi. Menyadari hal itu, pada tahun 2005 pihak pengurus Rukun Warga 15 membentuk sebuah organisasi pengelola pasar. Organisasi tersebut bertugas menjaga ketertiban dan keamanan pasar serta menarik retribusi dari para pedagang. Adanya penarikan retribusi yang digunakan untuk kepentingan masyarakat inilah yang kemudian membuat warga masyarakat Rukun Warga 15 secara berangsur-angsur dapat memaklumi keberadaan Pasar Wisata 46.

Secara perlahan Pasar Wisata 46 mengalami perkembangan, baik dari segi jumlah pedagang dan jenis-jenis barang yang diperdagangkan maupun jumlah pengunjung, bahkan fungsi pasar itu sendiri. Dalam hal ini tidak hanya berfungsi sebagai penyedia makanan dan minuman bagi orang-orang sedang berolahraga, tetapi juga bagi orang yang ingin berekreasi bersama keluarga, atau memang sengaja mencari barang-barang kebutuhan rumah tangga. Para pengunjung pun tidak lagi hanya berasal dari Rukun Warga 15, Kelurahan Cipadung dan asrama Krida Nusantara saja, melainkan dari wilayah lain di sekitar Kecamatan Cibiru, seperti: Manisi, Cisurupan, Palasari, dan Pasirbiru, Cipadung Kidul, Cipadung Kulon dan Kecamatan Cileunyi, seperti: Cibiru Wetan, Cibiru Hilir, Cibiru Kulon, Cikoneng, Jadaria, Pamubusan, Cibangkonol, Sindangreret, Warung Gede, Cibiru Tonggoh, Babakan Biru, Cibiru Indah, Cibiru Raya, Sadang, dan wilayah lain di sekitar kaki Gunung Manglayang.

\section{b. Pengelola Pasar Wisata 46}

Pengelola pasar berasal dari Rukun Warga 15, Kelurahan Cipadung. Mereka terdiri atas: ketua, bendahara, seksi keamanan dan ketertiban, serta seksi kebersihan. Ketua Pengelola Pasar yang tidak lain adalah Ketua Rukun Warga 15, dalam menjalankan tugasnya, khususnya dalam penarikan retribusi, dibantu oleh seorang bendahara. Bendahara setiap minggu bertugas menarik retribusi dari para pedagang. Besarnya retribusi antara Rp 2.500,00-Rp 10.000,00, bergantung dari besar-kecilnya lapak dan harga barang yang dijual. Pedagang yang hanya menjual berbagai jenis barang yang harganya relatif murah dan berlapak kecil cukup membayar retribusi antara Rp2.500,00-Rp.3.000,00. Sementara, pedagang yang berlapak agak besar dan menjual berbagai barang dengan harga yang relatif mahal dikenakan retribusi sebesar $\mathrm{Rp} \quad 4.000,00-\mathrm{Rp}$ $10.000,00$. Biaya ini belum termasuk pembelian air mineral yang berukuran 500 mililiter dengan merek Al Maksoum yang dijual oleh bendahara ketika menarik retribusi dengan harga sebesar $\mathrm{Rp}$ $2.000,00$.

Seseorang yang akan berjualan di Pasar Wisata 46 harus minta izin ke pengelola pasar melalui salah seorang satuan pengamanan pasar (hansip). Cara mendapatkan izin untuk berjualan cukup sederhana, yaitu melapor kepada salah 
seorang hansip yang ditempatkan di empat titik, yaitu: (1) di tempat parkir sepeda motor, (2) di samping SMP Negeri 46 Bandung, (3) di Jalan Kelurahan Cipadung, dan (4) di jalan masuk menuju perumahan Griya Cipadung Asri dan perumahan Dwipa Puri Residence. Hansip tersebut kemudian mencari lahan kosong agar pedagang baru dapat menggelar lapaknya (minimal satu minggu setelah pengajuan izin).

Untuk mengontrol keberadaannya, pihak pengelola pasar juga membentuk sebuah paguyuban agar antarpedagang dapat lebih mengenal satu sama lain, sehingga tidak saling berebut tempat berjualan. Jadi, apabila seorang pedagang telah ditempatkan di satu lokasi, pedagang tersebut hanya boleh berjualan di tempat itu dan tidak boleh pindah atau menempati lahan orang lain. Seorang pedagang baru boleh menempati lahan pedagang lain apabila pemiliknya tidak berjualan serta mendapat izin dari hansip yang sedang bertugas.

Pedagang yang telah menjadi anggota paguyuban, ketika berjualan diwajibkan mengenakan kaos oblong yang berwarna oranye. Kaos tersebut di bagian punggungnya bertuliskan "Paguyuban Pedagang Pasar Wisata 46 Kelurahan Cipadung". Selain itu, pedagang harus membawa kartu identitas anggota pedagang pasar. Kedua identitas tersebut (kaos oblong dan kartu anggota) bukan dibagikan secara percuma, melainkan harus dibeli dengan harga Rp 20.000,00 (untuk kaos oblong) dan $\mathrm{Rp} 25.000,00$ (untuk kartu anggota). Meskipun demikian, dalam kenyataannya hanya sekitar $10 \%$ saja yang tetap mematuhi aturan itu. Sedangkan, sebagian besar (90\%) sudah tidak mematuhi lagi dengan alasan lupa atau kaos oblong sudah tidak layak pakai.

Unsur pengelola pasar lainnya adalah petugas kebersihan dan tukang parkir. Petugas kebersihan berjumlah 6 orang yang mulai bekerja setelah pasar selesai (dari pukul 11.00-16.00 WIB).
Sementara, tukang parkir berjumlah 7 orang dengan rincian: 4 orang di jalan samping SMPN 46 (sepanjang 200 meter) dan 3 orang di lahan kosong milik seorang warga di Jalan Kelurahan Cipadung. Setiap minggunya, tukang parkir harus menyetorkan uang hasil parkirannya kepada bendahara pasar sebesar Rp 200.000,00, sedangkan sisanya dibagi secara merata.

Seluruh pendapatan, baik dari hasil retribusi, pembuatan kartu identitas, pembuatan kaos oblong, maupun parkir kendaraan bermotor (roda dua), dikumpulkan dan digunakan untuk berbagai keperluan, seperti: gaji pengelola pasar, kas Kecamatan Cibiru (sebagai pendapatan asli Kecamatan), dan kas Rukun Warga 15. Kas rukun warga inilah yang kemudian digunakan untuk perbaikan saluran air, perbaikan jalan, serta pembelian tanah wakaf yang berada di Dusun Jadaria, Kelurahan Cibiru Wetan, Kecamatan Cileunyi (sekitar satu kilometer arah selatan Perumahan Griya Cipadung Asri). Tanah wakaf tersebut digunakan sebagai pekuburan warga masyarakat Rukun Warga 15.

Kontribusi pedagang pasar pada Rukun Warga 15 inilah yang membuat warga masyarakat secara berangsur-angsur dapat memaklumi keberadaan Pasar Wisata 46. Mereka tidak hanya merasakan manfaat keberadaan pasar yang berupa perbaikan sarana umum dan ditiadakannya iuran wajib bulanan Rukun Warga 15, tetapi juga dapat dengan mudah membeli barang kebutuhan hidup sehari-hari tanpa harus pergi jauh dari rumah.

\section{c. Pedagang Pasar Wisata 46}

Menurut data yang diperoleh dari pihak pengelola Pasar Wisata 46, setiap minggu tercatat ada sekitar 390 pedagang. Dari ke-390 pedagang tersebut, hanya sekitar $2,05 \%$ (8 pedagang) yang berjualan di toko dan 2 pedagang $(0,51 \%)$ yang memanfaatkan halaman rumah warga sebagai tempat usaha (penjual ayam bakar dan jasa kereta api mini). Selebihnya 
adalah pedagang kaki lima yang menggunakan lapak-lapak kecil di sepanjang sisi Jalan Cigagak hingga Jalan Kelurahan Cipadung. Bentuk, bahan, dan ukuran lapak bergantung dari selera dan kemampuan pedagang. Jadi, ada lapak yang terbuat dari kain terpal plastik yang berukuran panjang antara 1-3,5 meter dan lebar 1-2 meter; ada lapak bambu atau aluminium yang dibuat sedemikian rupa dengan tinggi antara 1-2 meter; dan ada lapak kombinasi papan kayu dan bambu dengan panjang 1-3,5 meter, lebar 1-1,2 meter, tinggi kaki antara 0,5-1 meter. Selain itu, ada pula pedagang yang menggunakan gerobak (pedagang makanan), pikulan, kol dolak atau mobil bak terbuka (pedagang peralatan rumah tangga), dan pedagang yang mobile karena dagangannya dapat dibawa kemana-mana (pedagang balon dan serbet).

Apabila

diklasifikasikan berdasarkan jenis barang yang dijajakan, maka sedikitnya ada 14 golongan pedagang, yaitu: (1) pedagang sayurmayur dan bumbu dapur; (2) pedagang sandang; (3) pedagang buah-buahan; (4) pedagang peralatan rumah tangga; (5) pedagang audio dan video compact disc bajakan; (6) pedagang aksesoris tubuh; (7) pedagang aksesoris telepon genggam; (8) pedagang mainan anak-anak; (9) pedagang binatang peliharaan; (10) pedagang daging; (11) pedagang buku dan perlengkapan sekolah; (12) pedagang tanaman hias; (13) pedagang kuliner; dan (14) jasa penyewaan.

Pedagang sayur-mayur dan bumbu dapur berada mulai dari bagian samping SMP Negeri 46 Bandung (batas parkir kendaraan bermotor) hingga ke perumahan Dwipa Puri Residence. Adapun jenis sayur-mayur dan bumbu dapur yang dijajakan adalah: cabai, wortel, tomat, mentimun, kol, kelapa parut, kentang, jengkol, kangkung, tahu, tempe, oncom, bawang merah, bawang putih, kacang panjang, brokoli, daun bawang, buncis, pare, labu siam, petai, burkol, kacang merah, terong, ketela, pecai, leunca, jagung, surawung (kemangi), daun singkong, daun pepaya, kunyit, jahe, lengkuas, salam, sereh, gula merah, ketumbar, dan kemiri.

Pedagang sandang tersebar secara merata mulai dari depan halaman SMP Negeri 46 hingga ke Perumahan Dwipa Puri Residence (Jalan Kelurahan Cipadung). Adapun barang yang dijual meliputi berbagai macam pakaian, seperti: pakaian anak-anak, daster, jilbab, celana pendek, celana panjang, training, jaket, kopiah, topi, pakaian dalam, kemeja, kaos oblong, dan sweater.

Pedagang buah-buahan menjual berbagai macam buah (bergantung musimnya), seperti: pisang ambon, pisang tanduk, alpukat, rambutan, durian, salak, jeruk bali, semangka, apel, lengkeng, pepaya, mangga, jeruk, dan jambu. Untuk menggelar dagangannya, mereka ada yang menggunakan lapak terpal plastik, dan ada pula yang menggantungkannya pada pikulan yang terbuat dari bambu.

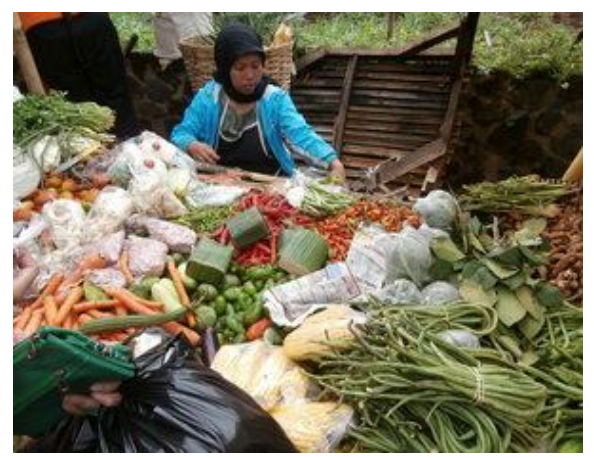

Gambar 1. Pedagang Sayur mayur. Sumber: Dokumen Pribadi.

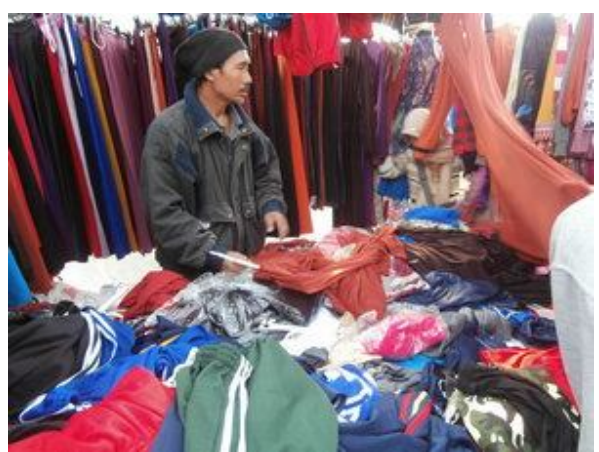

Gambar 2. Pedagang Sandang. Sumber: Dokumen Pribadi. 


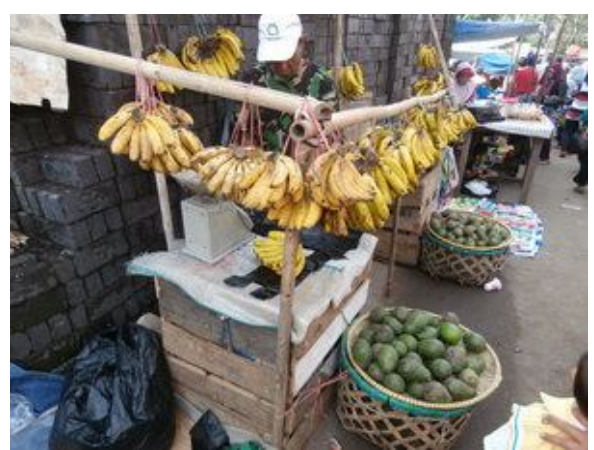

Gambar 3. Pedagang Buah.

Sumber: Dokumen Pribadi.

Pedagang peralatan rumah tangga menjual peralatan dapur seperti: panci, mangkuk, piring, gelas, kompor gas, wajan, pisau, loyang, saringan teh, ceret, cowet dan mutu, serok, katel, langseng); peralatan makan seperti: piring, mangkuk, gelas, sendok, garpu; peralatan kebersihan seperti: kapur barus, cairan pembersih kaca, cairan pembersih lantai, asbak sapu, serbet, racun tikus, sabun cuci, sabun colek; peralatan mandi seperti: sikat gigi, sabun mandi, wadah plastik tempat menaruh sikat gigi dan sabun mandi, shampoo, handuk, ember plastik, gayung; perkakas pertukangan dan kelistrikan seperti: palu, tang, paku, meteran, obeng kembang, obeng plus/minus, gergaji, gembok, kikir, remote televisi, baterai jam; peralatan perkebunan seperti: cangkul, sekop, selang, pot plastik; dan peralatan rumah tangga lainnya seperti: kursi plastik, gantungan baju, karpet plastik, sepatu, semir sepatu, gunting kuku, jerigen, bantal, guling, bed cover, gunting, hordeng, sisir, sisir suri, jarum dan benang jahit, jarum pentul, dan korek kuping.

Pedagang audio-visual (compact disc) berada di bagian tengah pasar. Jumlah mereka hanya tiga orang. Adapun barang yang diperdagangkan berupa video compact disc (VCD), digital video disc (DVD) dan lagu-lagu yang berformat MP3 (MPEG-1 Layer-3 audio). Oleh karena barang yang dijual berupa barang bajakan, harga per kepingnya baik VCD, DVD maupun MP3 tergolong murah, yaitu antara Rp 4.000,00-Rp 15.000,00.

Pedagang aksesoris tubuh menjual berbagai barang yang erat kaitannya dengan bagian-bagian tubuh sehingga terlihat indah. Barang-barang itu antara lain: gelang, kalung, cincin, penjepit rambut, bando, anting-anting, jam tangan, kacamata, sandal jepit, sepatu, ikat pinggang, parfum isi ulang, parfum nonalkohol, hingga tato temporer. Selain pedagang aksesoris tubuh, juga ada pedagang aksesoris telepon genggam. Mereka menjual barang-barang seperti: screen protector atau pelapis anti gores, sticker, penguat sinyal, dompet (wadah telepon genggam), chassing, charger, earphone, baterai telepon genggam, hingga karet atau plastik pelindung bagian bawah telepon genggam.

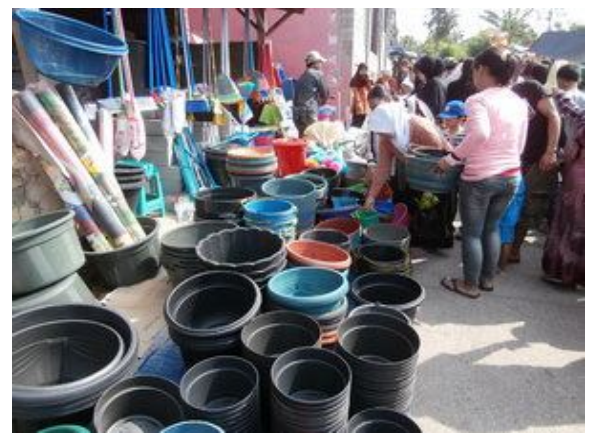

Gambar 4. Pedagang Peralatan Rumah Tangga. Sumber: Dokumen Pribadi.

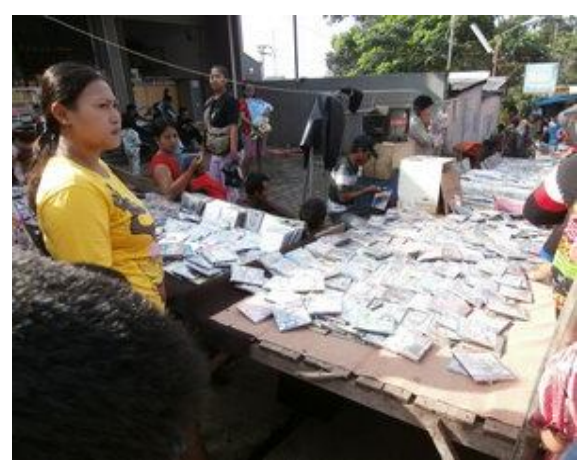

Gambar 5. Pedagang Audio-Visual.

Sumber: Dokumen Pribadi. 


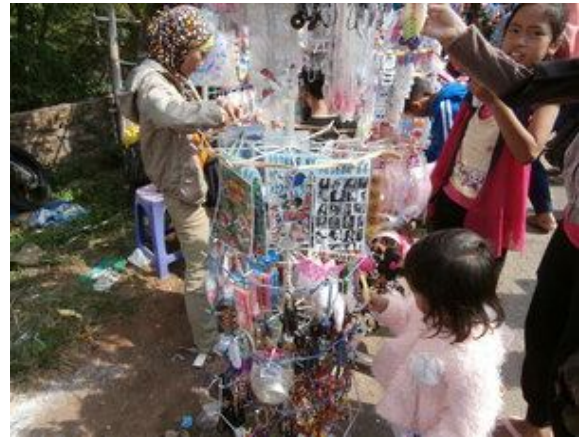

Gambar 6. Pedagang Aksesoris Tubuh Sumber: Dokumen Pribadi.

Pedagang mainan anak-anak menjual berbagai macam permainan anak, seperti: perahu kecil yang terbuat dari seng, sticker, poster, balon, pistol air, mobil-mobilan, motor-motoran, keretakeretaan, alat musik (mainan), rumahrumahan, kembang api, puzzle, terompet, kartu gambar, gasing plastik, bangbarongan, kendang kecil, kuda lumping, boneka, kapal-kapalan, dan binatang dari cangkang kerang.

Pedagang binatang peliharaan menjual berbagai binatang seperti: anak bebek, anak ayam yang dicelup dengan laurtan warna sehingga bulunya berwarnawarni, burung, hamster, ikan hias, dan kura-kura. Para pedagang ini juga menjual berbagai macam pakan dan kandang untuk binatang peliharaan, khususnya untuk anak ayam, anak bebek, dan hamster. Bahan kandang ada yang terbuat dari karton dan anyaman kawat, ada pula yang buatan pabrik yang berbahan besi dan plastik.

Pedagang daging hanya menjual daging ayam dan sapi. Sedangkan, ikan laut yang dijual oleh pedagang ada dua macam, yaitu ikan laut telah diasinkan (dibungkus dalam plastik kecil), dan ikan laut segar. Ikan laut tersebut, baik yang diasinkan maupun yang masih segar, diperoleh dari nelayan Pangandaran.

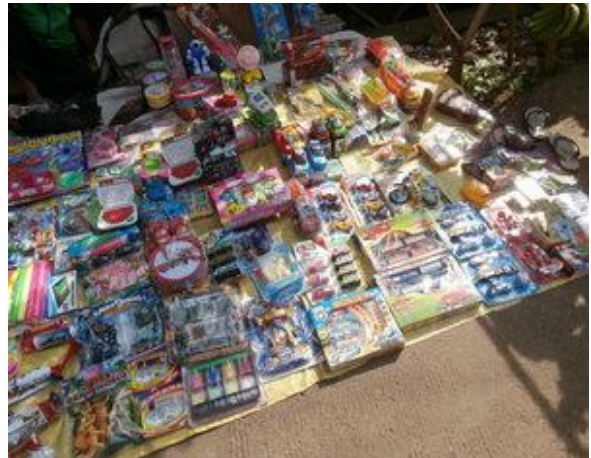

Gambar 7. Pedagang Mainan Anak. Sumber: Dokumen Pribadi.

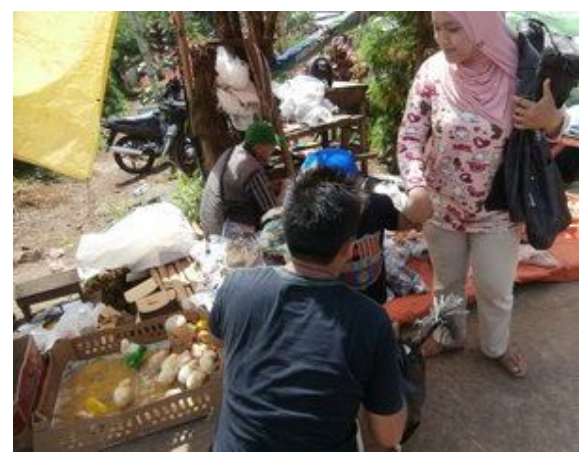

Gambar 8. Pedagang Binatang Peliharaan. Sumber: Dokumen Pribadi.

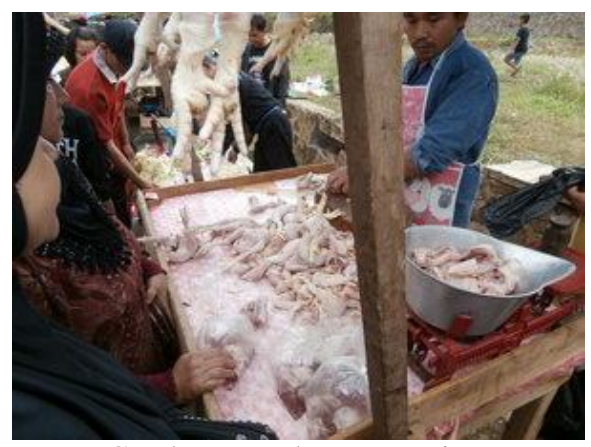

Gambar 9. Pedagang Daging.

Sumber: Dokumen Pribadi.

Pedagang buku dan perlengkapan sekolah menjual barang-barang seperti: buku tulis, buku gambar, buku islami, pensil, pulpen, penghapus, tempat pensil, penggaris, peraut, tas sekolah, dan lain sebagainya. Kemudian, pedagang tanaman hias menjual beberapa tanaman, seperti: sedap malam, cocor bebek dan lain sebagainya. Pedagang tanaman hias jumlahnya hanya seorang. Ia mangkal di 
bagian pangkal Jalan Cigagak, tepatnya sekitar 50 meter dari gerbang masuk Perumahan Dwipa Puri Residence. Barang dagangannya hanya ditempatkan dalam ember plastik yang berisi air, dan ada pula yang diikat lalu ditaruh begitu saja di atas tanah.

Pedagang kuliner menyediakan makanan dan minuman yang dapat dikonsumsi di tempat atau dibawa pulang (sebagai lauk-pauk di rumah). Adapun makanan dan minuman yang dapat dikonsumsi langsung di tempat, di antaranya adalah: surabi, batagor, kupat tahu, ayam bakar, cilok, bubur ayam, basreng, nagasari, bugis, cakue, balabala, sate kikil, onde-onde, sop buntut, nasi timbel, ikan bakar, nasi kuning, lontong opor ayam, duwegan, bandrek, kopi, combro, risoles, pisang molen, gehu, bolu, puding, lemper, kerupuk, dan lain sebagainya. Sedangkan, kuliner yang dibawa ke rumah adalah lauk-pauk, seperti: semur jengkol, semur telur, tempe kering, ayam goreng, ayam bakar, sate telur puyuh, telur dadar, terung bumbu, perkedel, semur cumi-cumi, ayam suwir, pepes ikan, pepes ayam, pepes tahu, ulukuteuk leunca, sayur kacang beureum, dan lain sebagainya. Para pedagang makanan ini ada yang menggunakan gerobak, pikulan, lapak plastik dan kayu, atau menyewa halaman rumah penduduk untuk disulap menjadi warung.

Pedagang yang menyewa halaman rumah penduduk untuk dijadikan warung makan hanya satu orang. Warung tersebut menyediakan: kupat tahu petis, kupat tahu sayur, nasi kuning, nasi timbel, ikan dan ayam bakar, duwegan, bandrek, dan kopi. Untuk dapat menggunakan halaman tersebut pemilik warung harus menyewa kepada pemilik rumah sebesar Rp5.000.000,00 per tahun dengan fasilitas bebas menggunakan listrik serta air. Selain itu, juga harus membayar pada pihak RW 15 sebesar Rp10.000,00 sebagai uang retribusi.

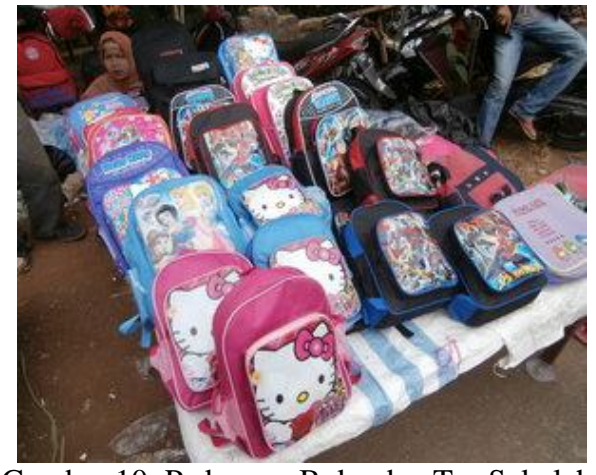

Gambar 10. Pedagang Buku dan Tas Sekolah. Sumber: Dokumen Pribadi.

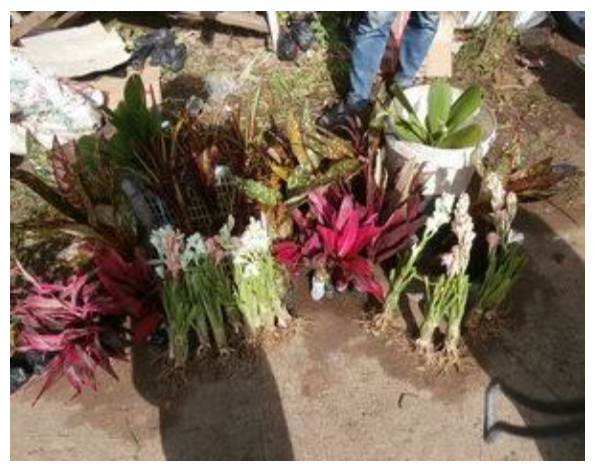

Gambar 11. Pedagang Tanaman Hias. Sumber: Dokumen Pribadi.

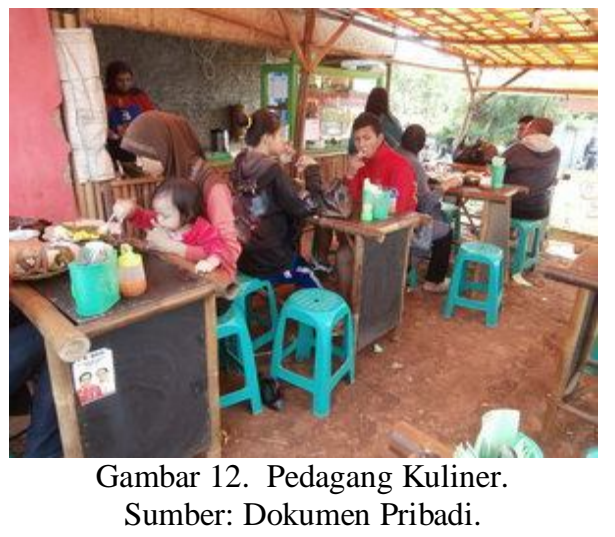

Selain pedagang, di sekitar pintu gerbang SMP Negeri 46 Bandung ada tiga orang yang menyewakan odong-odong. Odong-odong adalah sebuah permainan, khususnya untuk kanak-kanak, yang bentuknya sedemikian rupa sehingga anak yang naik merasa senang. Tidak jauh dari odong-odong, ada yang menyewakan kereta api mini yang berkapasitas delapan anak (empat gerbong). Sebelum 
beroperasi, pada pertengahan tahun 2011, pemilik kereta api mini melakukan survei selama empat bulan dengan cara mencatat jumlah anak yang berusia sekitar 3-12 tahun yang ikut orang tua mereka berbelanja di Pasar Wisata 46. Hal ini didasarkan pada pengalaman sebelumnya yang selalu merugi ketika membuka jasa permainan kereta api mini di beberapa tempat sekitar Kabupaten Bandung, karena tidak memperhitungkan jumlah pengunjung dari kalangan kanak-kanak.

Bagi anak yang ingin naik kereta api mini, pemilik mematok harga karcis sebesar Rp5.000,00 untuk lima menit bermain. Agar lebih menarik minat orang tua, apabila berhasil mengumpulkan lima buah karcis dapat menukarkannya kembali untuk satu kali bermain secara gratis.

Jasa penyewaan lainnya adalah kuda tunggangan yang setiap minggunya berjumlah antara 2 hingga 5 ekor. Kudakuda yang disewakan bukanlah kuda pacu atau kuda penarik kereta, melainkan kudakuda yang terlatih (dapat menari), sebagaimana kuda dalam pentas kesenian kuda renggong. Ketika disewakan, kuda dilengkapi dengan sela (tempat atau alat untuk duduk penunggang kuda), seser (pembalut kepala kuda), sanggawedi (pijakan kaki bagi penunggang), apis buntut (tali penahan sela yang dihubungkan dengan pangkal ekor kuda), eles (tali kemudi kuda), kadali (besi yang dipasang pada mulut kuda untuk mengikatkan tali kendali), ebeg (hiasan sela), sebrak (lapisan di bawah sela agar punggung kuda tidak luka/lecet), dan andong (sabuk yang diikatkan ke bagian perut kuda sebagai penguat sela agar tidak mudah lepas dari punggung kuda). Harga sewanya hanya sebesar Rp3.000,00 untuk sekali jalan (pergi-pulang sejauh sekitar 200 meter).

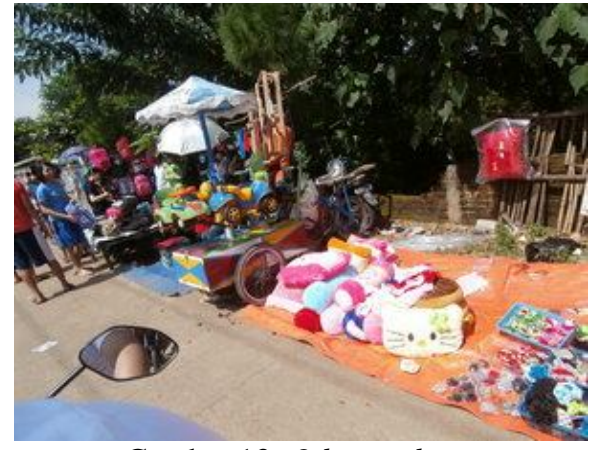

Gambar 13. Odong-odong. Sumber: Dokumen Pribadi.

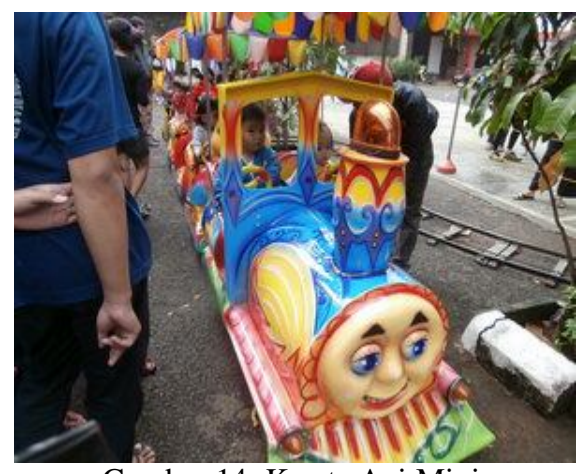

Gambar 14. Kereta Api Mini. Sumber: Dokumen Pribadi.

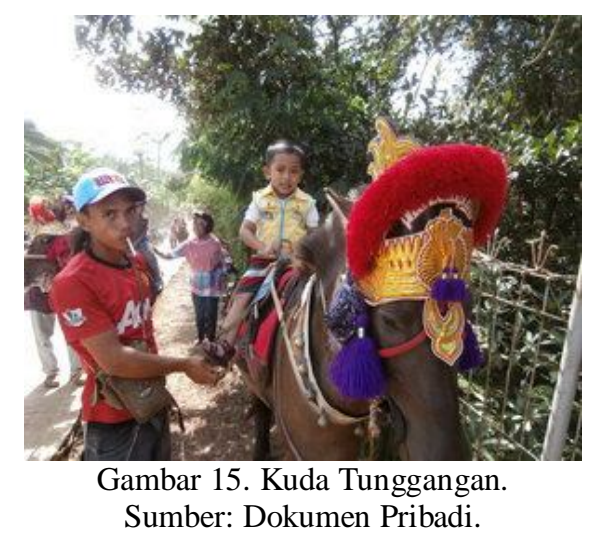

3. Pasar Wisata Cibiru

a. Letak dan Gagasan Pendirian Pasar Wisata Cibiru

Jika Pasar Wisata 46 berada di sepanjang Jalan Cigagak, tepatnya di depan SMP Negeri 46 Bandung dan Griya Cipadung Asri, maka Pasar Wisata Cibiru berada di sebuah lahan tersendiri. Gagasan awal pendirian Pasar Wisata Cibiru berasal dari LSM setempat yang bernama Forum 
Komunikasi Pemuda Peduli Lingkungan (FKPPL) Kecamatan Cibiru. Gagasan itu bermula dari keberadaan para pedagang yang memanfaatkan pinggiran Jalan Cigagak sebagai tempat berjualan. Adapun tujuannya adalah agar para pedagang tidak lagi berjualan di pinggir jalan. Untuk mewujudkannya, pada awal tahun 2012 FKPPL bekerjasama dengan Bank Rakyat Indonesia membangun sekitar 250 unit kios di lahan milik warga bernama Rully yang letaknya sekitar 200 meter dari SMP Negeri 46 Bandung (Wawan, 2012).

Luas Pasar Wisata Cibiru sekitar 2.000 meter persegi. Pasar ini berisi sekitar 250 buah kios. Setiap kios berukuran panjang 1,5 meter, lebar 2 meter, tinggi 4 meter, dan beratap asbes. Antarkios dalam satu los hanya dipisahkan oleh triplek yang berukuran lebar 1,5 meter dan tinggi 1,5 meter. Bagian depan dan sisi kiri pasar berfungsi sebagai areal parkir. Areal tersebut dapat menampung 40-50 sepeda motor. Sementara, di sisi kanan difungsikan sebagai kantor pemasaran dan sekaligus pengelola pasar. Bagian berikutnya adalah blok atau los makanan dan minuman. Sementara, kios-kios yang ada di los sayuran dan lauk pauk belum seluruhnya siap untuk ditempati (pembangunannya belum selesai).

\section{b. Pengelola Pasar Wisata Cibiru}

Jika pengelola Pasar Wisata 46 adalah Rukun Warga 15, Kelurahan Cipadung yang diketuai oleh Ketua Rukun Warganya, maka Pasar Wisata Cibiru dikelola oleh LSM setempat yang bernama "Forum Komunikasi Pemuda Peduli Lingkungan (FKPPL)" Kecamatan Cibiru. Oleh pengelola, setiap kios di Pasar Wisata Cibiru ini disewakan sebesar $\mathrm{Rp}$ 8.000.000,00 untuk jangka waktu selama 10 tahun. Adapun pembayarannya dapat secara kontan atau dengan uang muka sebesar $\mathrm{Rp}$ 4.000.000,00. Sedangkan, sisanya diangsur per bulan. Untuk saat sekarang, besaran dan waktu pembayaran angsuran masih bergantung pada kesanggupan penyewa dan belum ditetapkan oleh pihak pengelola pasar karena jumlah penyewa masih sedikit. Biaya tersebut belum termasuk pemasangan papan kayu penutup kios atau rolling dor (pintu penutup yang terbuat dari besi yang berfungsi sebagai pengaman). Apabila penyewa menghendaki pemasangan pengaman kios yang terbuat dari papan kayu, ia harus membayar lagi sebesar Rp1.000.000,00. Lalu, apabila menghendaki pemasangan pengaman kios yang terbuat dari rolling door (besi), maka ia harus membayar lagi sebesar Rp 2.000.000,00.

\section{c. Pedagang Pasar Wisata Cibiru}

\begin{tabular}{lccc}
\multicolumn{1}{c}{ Pasar } & Wisata & Cibiru mulai \\
beroperasi & sekitar & tahun & 2012. \\
Sebagaimana & telah & disinggung,
\end{tabular} pengoperasian pasar ini adalah sebagai antisipasi dari bertambahnya jumlah pedagang di Pasar Wisata 46 yang menimbulkan dambak berupa menyempitnya ruas di sepanjang Jalan Cigagak hingga ke Jalan Desa Cipadung, atau mulai dari SMP Negeri 46 Bandung melewati Perumahan Dwipa Puri Residance hingga mendekati Apotik Komunitas Sehat. Padahal, menurut antara2titik.com, pada kesepakatan awal antara pedagang dengan pihak pengelola pasar, mereka hanya diperbolehkan berjualan di depan SMP Negeri 46 Bandung.

Jumlah pedagang yang berjualan di Pasar Wisata Cibiru ini relatif sedikit dibandingkan jumlah pedagang yang ada di Pasar Wisata 46. Blok atau los yang diperuntukkan bagi para pedagang makanan dan minuman misalnya, blok ini hanya diisi oleh beberapa pedagang makanan, seperti: lotek dan rujak, bakso dan mie ayam, nasi kuning, kupat tahu, lontong kari, dan asinan. Bahkan, blok pakaian dan peralatan sekolah baru diisi oleh 5 pedagang, dengan rincian: 4 pedagang pakaian anak dan muslimah, dan seorang pedagang tas sekolah. Sementara, kios-kios yang ada di los sayuran dan lauk pauk belum seluruhnya siap untuk 
ditempati (pembangunannya belum selesai). Selain blok-blok dan kios-kios yang diperuntukkan bagi para pedagang, pasar ini juga dilengkapi fasilitas umum berupa sebuah musholla dan 10 buah kamar kecil. Kedua fasilitas tersebut juga masih dalam proses penyelesaian.

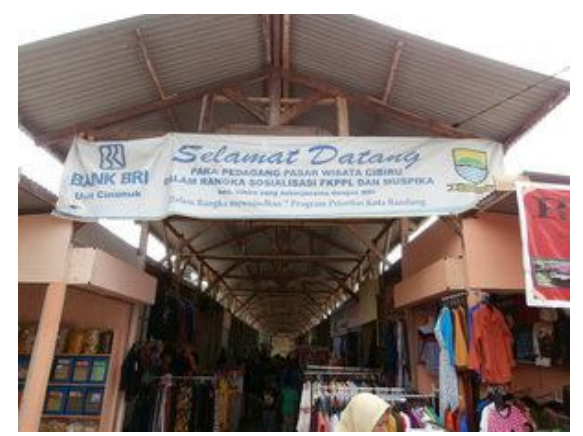

Gambar 16. Pasar Wisata Cibiru. Sumber: Dokumen Pribadi.

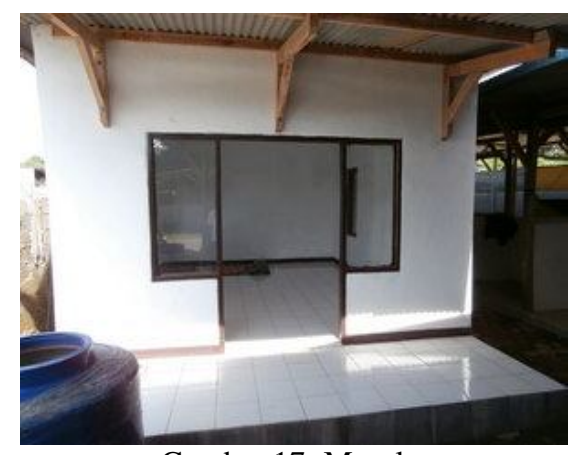

Gambar 17. Musala. Sumber: Dokumen Pribadi.

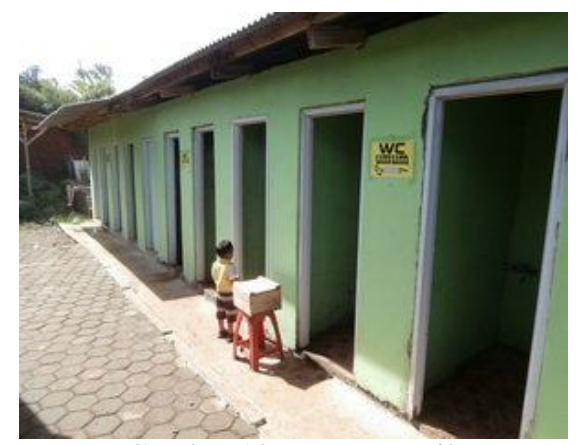

Gambar 18. Kamar Kecil. Sumber: Dokumen Pribadi.

\section{Minat Pedagang Pasar Wisata 46 terhadap Pasar Wisata Cibiru}

Apabila ditinjau dari segi

kenyamanan dan kebersihan, Pasar Wisata Cibiru jauh lebih nyaman dan bersih daripada Pasar Wisata 46. Sebab, Pasar Wisata Cibiru menyediakan kios yang relatif bersih, terlindung dari sinar matahari, serta memiliki sarana penunjang yang berupa musala, area parkir, dan toilet. Akan tetapi, berdasarkan pengamatan dari mulai berdirinya Pasar Wisata Cibiru pada tahun 2012 hingga saat ini hanya beberapa kios di bagian depan saja yang sudah terisi, sisanya masih kosong. Pasar Wisata Cibiru belum sepenuhnya mampu menggantikan kedudukan Pasar Wisata 46. Hal ini diperkuat oleh keterangan pihak pengelola pasar yang mengatakan bahwa dari 250 buah kios yang tersedia hanya 90 buah yang terisi. Itu pun, dalam kenyataannya setiap hari hanya ada 6-10 orang pedagang saja yang berjualan. Pedagang lainnya ada yang masih menunggu hingga kondisi pasar berjalan normal (jumlah pedagang banyak dan buka setiap hari); mengoperkontrakkan lagi kepada orang lain karena dinilai tidak memiliki prospek cerah; dan bahkan ada yang ikut berjualan kaki lima di Pasar Wisata 46 sambil menunggu kondisi pasar normal.

Sepinya pedagang di Pasar Wisata Cibiru disebabkan oleh berbagai faktor, antara lain kurang tanggapnya pengelola pasar terhadap hasil sosialisasi yang dilakukannya. Dalam hal ini penulis sependapat dengan apa yang dikatakan Wawan (2012) bahwa ketika diadakan sosialisasi terhadap warga masyarakat RW 15 dan pedagang, hanya warga masyarakat yang meresponnya dengan baik. Sebab, dapat mengurangi kepadatan di sepanjang Jalan Cigagak hingga Jalan Kelurahan Cipadung. Sementara, para pedagang banyak yang kurang setuju dan lebih memilih tetap berjualan di Pasar Wisata 46. Adapun faktor-faktor penyebab kekurangsetujuan para pedagang di antaranya adalah sebagai berikut. 


\section{a. Lokasi Pasar Cibiru Kurang Strategis}

Bagi sebagian pedagang, lokasi pasar yang berada dalam satu tempat akan memengaruhi jumlah pengunjung yang berbelanja. Mereka menilai, pengunjung sudah terbiasa dengan bentuk Pasar Wisata 46 yang memanjang mengikuti jalan. Apabila tidak seluruh pedagang pindah ke Pasar Wisata Cibiru, maka akan kalah bersaing dengan pedagang yang masih bertahan di Pasar Wisata 46. Selain itu, tujuan pengunjung bukanlah semata-mata untuk berbelanja, tetapi juga berekreasi melepas rutinitas keseharian sambil menikmati keindahan kaki Gunung Manglayang. Apabila disamakan dengan pasar tradisional pada umumnya, dikhawatirkan pengunjung akan beralih ke pasar tradisional lain yang lebih lengkap dan sudah lama berdiri di daerah Ujungberung dan Cileunyi karena fungsinya sama atau bahkan ke pasar swalayan (supermarket dan minimarket) yang biasanya lebih mementingkan kebersihan dan kenyamanan berbelanja.

\section{b. Ukuran Kios yang Relatif Kecil dan Sewanya Relatif Mahal}

Kios yang ada di Pasar Wisata Cibiru berukuran relatif kecil (hanya 1,5×2,0 meter). Kios yang berukuran seperti itu hanya cocok bagi pedagang kecil yang jumlah barang dagangannya sedikit. Sedangkan, pedagang yang agak besar membutuhkan kios dengan panjang antara 3-4 meter. Oleh karena itu, pedagang tersebut harus menyewa lebih dari satu unit kios. Padahal, harga sewa kios relatif mahal, yaitu $\mathrm{Rp} 8.000 .000,00$ per kios. Selain itu, retribusi yang harus dibayar setiap harinya juga relatif mahal, yaitu Rp 5.000,00. Sementara, retribusi di Pasar Wisata 46 hanya sekitar Rp 2.500,00 per minggunya, atau setiap kali berjualan. Biaya sewa kios dan retribusi yang relatif mahal tentu saja akan menimbulkan masalah tersendiri bagi para pedagang Pasar Wisata 46 yang pada umumnya berskala menengah ke bawah.

\section{c. Status Para Pedagang Pasar Wisata 46}

Status para pedagang yang ada di Pasar Wisata 46 dapat dikategorikan sebagai pedagang kaki lima yang bermodal kecil dan sebagian besar bukan pedagang tetap. Artinya, usaha dagang yang mereka lakukan bukan sebagai mata pencaharian utama, tetapi sebagai mata pencaharian sambilan. Apabila tidak sedang berjualan sebagian dari mereka ada yang menjadi satuan pengamanan (satpam) di beberapa perusahaan, tukang ojeg, petani di sekitar Gunung Manglayang, buruh pabrik di daerah Ujungberung dan Rancaekek, pengurus desa di Kecamatan Cileunyi, ibu rumah tangga, dan lain sebagainya. Selain itu, ada juga yang menganggap berdagang di Pasar Wisata 46 hanya sebagai uji coba untuk merintis usaha baru dengan segmen menengah ke bawah. Jadi, Pasar Wisata 46 digunakan sebagai ajang pengujian diri untuk mengetahui layak atau tidaknya menjadi pedagang melalui indikator jumlah pengunjung, transaksi jual beli, dan jenis produk yang diminati. Apabila indikator-indikator tersebut menunjukkan hal yang positif, maka mereka akan serius menekuni usaha tersebut.

Sementara, pihak pengelola Pasar Wisata Cibiru hanya melihat dari satu sisi saja. Dalam hal ini apabila pedagang beralih ke Pasar Wisata Cibiru, maka tidak akan terjadi lagi kesemrawutan di sekitar Jalan Cigagak hingga Jalan Desa Cipadung. Selain itu, Pasar Wisata Cibiru juga dapat meningkatkan pendapatan asli Kecamatan Cibiru serta membuka lapangan kerja baru bagi warga masyarakat di sekitar Rukun Warga 15. Pengelola pasar tidak memperkirakan jika para pedagang kaki lima telah menempati kios, maka mereka akan masuk ke dalam sektor formal karena telah menjadi pedagang tetap di pasar yang mengorganisasikan kegiatannya dengan lebih sistematis dan dengan modal usaha yang lebih besar. Padahal, pedagang kaki lima, yang hanya menggunakan sisi jalan untuk menggelar dagangannya, termasuk dalam usaha sektor 
informal dengan modal berskala kecil dan bahkan ada yang mengambil barang dagangan dari juragan atau tokoh yang menjadi patronnya.

Pihak pengelola juga tidak terlalu rinci mempertimbangkan kondisi dari para pedagang kaki lima dan konsumennya (pembelinya). Mereka hanya berpendapat bahwa apabila dibangun pasar yang lebih besar, lebih baik, dan lebih megah, maka pasar tersebut akan semakin ramai. Dengan perkataan lain, pengunjung dan atau pembeli akan datang dengan sendirinya. Mereka kurang atau tidak memperhatikan bahwa ada Pasar Wisata 46 yang sudah terlebih dahulu beroperasi dan menarik banyak pengunjung.

\section{PEN UTUP}

Pasar Wisata 46 merupakan "pasar kaget" yang memanfaatkan sisi Jalan Cigagak hingga Jalan Kelurahan Cipadung. Pasar ini hanya digelar seminggu sekali, yaitu pada hari Minggu. Para pedagangnya sebagian besar adalah pedagang kaki lima (sektor informal) yang bermodal kecil. Sebagian besar dari mereka menganggap bahwa berdagang di pasar kaget ini bukan merupakan matapencaharian pokok, tetapi mata pencaharian sambilan. Bahkan, ada yang menganggap sebagai sarana uji coba dalam merintis usaha baru. Sementara, Pasar Wisata Cibiru adalah sebuah pasar yang lokasinya berada di suatu tempat (bukan di sepanjang jalan) dan menyediakan fasilitas yang lebih lengkap dan permanen, mulai dari blok/los, kios, areal perkir, tempat peribatan (musala), sampai kamar kecil. Pasar ini didirikan untuk mewadahi para pedagang yang ada di Pasar Wisata 46, sehingga mereka tidak memanfaatkan Jalan Cigagak dan Jalan Kelurahan Cipadung sebagai tempat untuk berjualan.

Meskipun demikian, Pasar Wisata Cibiru tidak serta merta menggeser secara keseluruhan keberadaan Pasar Wisata 46. Bahkan, sebagian besar $(76,92 \%)$ para pedagang Pasar Wisata 46 enggan untuk beralih ke Pasar Wisata Cibiru. Hal itu tercermin dari para pedagang Pasar Wisata 46 yang jumlahnya sekitar 390 orang, hanya 90 orang yang menyewa kios di Pasar Wisata Cibiru. Itupun, hanya sekitar 10-12 orang yang mau menempati kios dan berjualan setiap hari di sana. Sedangkan, selebihnya ada yang mengoper-kontrakkan kembali pada pedagang lain dan ada pula yang hanya menyewa kios tetapi tetap menjadi pedagang kaki lima sambil menunggu Pasar Wisata Cibiru beroperasi secara normal.

Adapun faktor-faktor yang membuat para pedagang enggan untuk beralih ke Pasar Wisata Cibiru, di antaranya adalah: lokasi pasar dinilai kurang strategis bagi transaksi jual-beli, ukuran lapak atau kios relatif kecil terutama bagi pedagang yang relatif besar, biaya sewa relatif mahal (Rp 8.000.000,00 per 10 tahun), retribusi juga relatif mahal (Rp 5.000,00 per hari, sementara di Pasar Wisata 46 hanya kurang lebih Rp 2.500,00 per minggu), dan status dari pedagang itu sendiri yang masuk dalam kategori usaha sektor informal yang bermodal kecil. Selain itu, masih adanya sebagian pedagang yang menganggap bahwa berjualan di Pasar Wisata 46 hanya merupakan pekerjaan sambilan dan atau sebagai uji coba untuk merintis usaha baru.

Dari sudut masyarakat sekitarnya, walaupun keberadaan Pasar Wisata 46 pada awalnya dianggap sebagai pengusik ketenteraman, namun dalam perkembangannya menjadi asset masyarakat Rukun Warga 15, Kelurahan Cigadung. Oleh karena itu, saran penulis Pasar Wisata 46 perlu dilestarikan karena itu merupakan salah satu identitas masyarakat Kelurahan Cigadung, khususnya masyarakat Rukun Warga 15. Apalagi, pasar ini memiliki kekhasan tersendiri, yaitu digelar seminggu sekali. Sementara, Pasar Wisata Cibiru digelar setiap hari. Dengan demikian, keduanya dapat berjalan secara berdampingan.

\section{DAFTAR SUMBER}




\section{Jurnal, Makalah, Laporan Penelitian, Skripsi, dan Tesis}

Widjajanti, Retno. 2009.

"Karakteristik Aktivitas Pedagang Kaki Lima pada Kawasan Komersial di Pusat Kota, Studi Kasus: Simpang Lima Semarang", dalam Jurnal Teknik Vol. 30 No 3. Tahun 2009 Universitas Diponegoro.

Putra, Wicak Hardhika. 2010.

Keberadaan dan Perkembangan Pasar Kaget Rawajati Jakarta. Tesis, Program Pascasarjana Magister Teknik Pembangunan Wilayah dan Kota Universitas Diponegoro, Semarang.

\section{Buku}

Ginanjar, Nugraha Jiwapraja. 1980.

Masalah Ekonomi Mikro. Jakarta: Acro.

Sadilah, Emiliana, Christiyati Aliani, Ismi Herawati, Moertipto, dan Sukali. 2011. Eksistensi Pasar Tradisional: Relasi dan Jaringan Pasar Tradisional di Kota Semarang, Jawa Tengah, Yogyakarta: Balai Pelestarian Sejarah dan Nilai Tradisional Yogyakarta, Direktorat Jenderal Nilai Budaya, Seni dan Film, Kementerian Kebudayaan dan Pariwisata

Stanton, William J. 1996.

Prinsip Pemasaran. Jakarta: Erlangga.

Sumintarsih, Taryati, Suyani, Dubar Adiyanto, dan Sujarno. 2011.

Eksistensi Pasar Tradisional: Relasi dan Jaringan Pasar Tradisional di Kota Surabaya, Jawa Timur, Yogyakarta: Balai Pelestarian Sejarah dan Nilai Tradisional Yogyakarta, Direktorat Jenderal Nilai Budaya, Seni dan Film, Kementerian Kebudayaan dan Pariwisata

\section{Internet}

Wawan. 2012. "Rumor di balik Pasar Wisata Cibiru Bermartabat", diakses dari http://maklumat-independen. com/daerah/jawa/871-rumor-dibalikpasar-wisata-cibiru-bermartabat.html, tanggal 8 Januari 2014, pukul 13.30 WIB.

"Warga Bangun Pasar Tradisional Cibiru", diakses dari http://antara2titik.com/ warga-bangun-pasar-tradional-cibiru/, tanggal 9 Januari 2014, pukul 12.45 WIB. 